\title{
GAMBARAN TINGKAT KEPUASAN IBU YANG BERSALIN PADA BIDAN DAN DUKUN BAYI DI WILAYAH KERJA PUSKESMAS ARJASARI KABUPATEN BANDUNG
}

\author{
Suci Noor Hayati* \\ *Sekolah Tinggi Ilmu Keperawatan PPNI Jawa Barat \\ Jl. Muhammad No. 34A Bandung 40173 \\ Telp. 022-6004498, 022-6121914, Fax.022-6121914 \\ Email:suci.noor@rocketmail.com
}

\begin{abstract}
Abstrak
Tingginya angka kematian ibu dan bayi di Indonesia terutama di Kota Bandung diakibatkan masih banyaknya pertolongan persalinan yang dilakukan oleh Dukun Bayi. Tujuan penelitian ini yaitu untuk mengetahui perbedaan tingkat kepuasan ibu yang bersalin di Wilayah Kerja Puskesmas Arjasari Kabupaten Bandung. Metode yang digunakan dalam penelitian ini yaitu deskriptif. Sampel berjumlah 75 orang, yang terdiri dari 35 orang ibu yang bersalin pada dukun bayi dan 40 orang ibu yang bersalin pada bidan, diambil dengan teknik simple random sampling. Analisa data dengan menggunakan analisis univariat. Hasil penelitian pada pertolongan persalinan yang dilakukan oleh Bidan berdasarkan analisis kuadran terdapat dua unsur pada kuadran II dan tiga unsur pada kuadran III. Tidak terdapat unsur pada kuadran I dan IV. Sedangkan pada pertolongan persalinan yang dilakukan oleh Dukun Bayi terdapat dua unsur pada Kuadran I, satu unsur pada kuadran II, satu unsur pada kuadran III dan satu unsur pada kuadran IV.
\end{abstract}

Kata Kunci : kepuasan, bidan, dukun bayi.

\begin{abstract}
The high mortality rate of mothers and babies in Indonesia, especially in the city of Bandung due to the number of birth help provided by traditional medical practioner. The purpose of this study is to determine the difference in maternal satisfaction rates in the Work Area Puskesmas Arjasari Bandung regency. The method used in this research is descriptive. The sample consisted of 75 people, consisting of 35 maternal mothers in the dukun bayi and 40 maternal mothers in the midwife, were taken by purposive sampling technique. Data analysis using univariate analysis. This study used a descriptive research method. Samples were 75 women, comprised with 35 by traditional medical practitioners and 40 by midwifes, and were chosen with purposive sampling. Questionnaires were used as the instruments in this study. Data analysis technique by using univariate analysis. The result showed there were two elements in $2^{\text {nd }}$ quadrant by midwife based on quadrant analysis and three elements in $3^{\text {rd }}$ quadrant. There was no elements in $1^{\text {st }}$ and $4^{\text {th }}$ quadrant. There were two elements in $1^{\text {st }}$ quadrant, one element in $2^{\text {nd }}$ until $4^{\text {th }}$ quadrant by traditional medical practioners.
\end{abstract}

Keywords : satisfaction, midwife, traditional medical practioner. 


\section{PENDAHULUAN}

Angka kematian ibu dan angka kematian bayi karena melahirkan di Indonesia sekitar 75$80 \%$ masih ditolong dukun terutama di pedesaan. Penyebab kematian terjadi terutama karena perdarahan, infeksi, dan keracunan hamil, serta lambatnya sistem rujukan (Ida Bagus, 1999).

Angka Kematian Ibu (AKI) di Indonesia tahun 2006 yaitu 290,8 per 100.000 kelahiran hidup. Target yang diharapkan dapat dicapai pada tahun 2009 adalah angka kematian ibu menjadi 226 per 100.000 kelahiran hidup melalui pelaksanaan. MPS (Making Pregnancy Safer) yaitu setiap persalinan ditolong oleh tenaga kesehatan terlatih (Depkes, 2007). Sementara persentase penolong persalinan oleh Dukun Bayi masih cukup tinggi yaitu 43,05\% pada tahun 2003 dan $42,5 \%$ pada tahun 2004, sehingga perlu pemantauan pengetahuan akan pentingnya kesehatan bagi dukun (Indikator Kesra Sulsel, BPS 2004).

Saat ini telah ada pelatihan dukun untuk menangani persalinan. Keberadaan tenaga penolong persalinan sangat diharapkan masyarakat terutama ibu bersalin. Demikian juga bagi Dukun Bayi sebagai tenaga penolong persalinan yang dibentuk dari kebudayaan masyarakat, tentulah keberadaannya sangat diharapkan dan harus selalu memperhatikan kualitas pelayanannya. Secara tidak langsung terdapat persaingan diantara kedua penolong persalinan tersebut. Untuk memenangkan persaingan, penolong persalinan harus mampu memberikan kepuasan kepada kliennya (Supranto, 2006).

Klien yang puas merupakan aset yang sangat berharga karena apabila klien puas mereka akan terus melakukan pemakaian terhadap jasa pilihannya, tetapi jika klien merasa tidak puas mereka akan memberitahukan dua kali lebih hebat kepada orang lain tentang pengalaman buruknya. Untuk menciptakan kepuasan klien, bidan sebagai tenaga kesehatan harus menciptakan dan mengelola suatu sistem untuk memperoleh klien yang lebih banyak dan kemampuan untuk mempertahankan kliennya tersebut. Dan kemampuan inilah yang harus dimiliki bidan sebagai tenaga kesehatan. Sehingga jumlah ibu yang bersalin pada bidan semakin meningkat. Tingkat kepuasan klien juga merupakan feedback kepada bidan sebagai tenaga kesehatan untuk keberhasilan program persalinan.

Berdasarkan studi pendahuluan yang telah dilakukan pada Kecamatan Arjasari jumlah persalinan yang ditolong oleh dukun terlatih sebesar 156 orang sedangkan jumlah persalinan yang ditangani oleh sebanyak 309 orang (Dinkes, 2008). Jumlah Dukun Bayi pada wilayah tersebut berjumlah 34 orang dengan rincian Desa Ancol Mekar 2 orang, Desa Rancakole 3 orang, Desa Patrolsari 4 orang, Desa Pinggirsari 21 orang, Desa Arjasari 4 orang. Sedangkan yang bertugas pada kecamatan tersebut hanya berjumlah lima orang, terdiri dari 1 orang dokter umum dan 4 bidan.

Pada tahun 2008 kematian bayi akibat persalinan oleh Dukun Bayi berjumlah 11 orang dan jumlah kematian ibu dengan persalinan oleh Dukun Bayi sebesar 5 orang (Data Puskesmas Arjasari, 2009). Pada pertolongan persalinan yang dilakukan oleh bidan tidak ditemukan kasus kematian. Kepuasan ibu bersalin merupakan penilaian subyektif berdasarkan harapan dan pengalamannya. Dari hasil wawancara yang dilakukan pada tiga orang ibu bersalin menggambarkan tingkat kepuasan yang berbeda-beda pada tiap unsur dalam determinan kualitas mutu. 


\section{METODE PENELITIAN}

Desain yang dipakai dalam penelitian ini adalah metode penelitian deskriptif. Variabel dalam penelitian ini adalah kepuasan ibu bersalin. Adapun sub variabel dari penelitian ini adalah unsur-unsur/determinan kualitas mutu yaitu kehandalan (reliability), ketanggapan (responsiveness), keyakinan (confidence), empati (empathy, berwujud (tangibels).

Populasi dalam penelitian ini adalah seluruh ibu yang pernah bersalin di Wilayah Kerja Puskesmas Arjasari, sejumlah 465 orang. Berdasarkan rumus slovin didapatkan sampel 39 orang untuk ibu yang bersalin pada bidan dan 35 orang untuk ibu yang bersalin pada dukun bayi. Pada penelitian ini pengumpulan data diawali dengan memilih subyek yang tepat dengan cara simple random sampling dengan menggunakan kuesioner yang diadopsi dari nursalam dengan skala likert.

Jumlah pernyataan pada kuesioner sebanyak 20 pernyataan. Teknik pengumpulan melalui penyebaran angket tentang faktor-faktor yang berkontribusi terhadap tingkat kepuasan ibu bersalin berdasarkan pada harapan dan pengalaman yang terdiri dari lima dimensi (kehandalan (reliability), ketanggapan (responsiveness), keyakinan (confidence), empati (empathy), berwujud (tangibels)). Setelah itu dilakukan uji validitas dengan metode koefisien korelasi product Moment dengan hasil uji validitas terdapat 3 item yang nilainya $\leq 0,300$. Sedangkan uji realibilitas dengan menggunakan koefisien Alpha Cronbach didapatkan hasil nilai uji realiobitas $\geq 0,700$. Teknik analisa data pada penelitian ini menggunakan teknik analisa univariat. Analisis ini dilakukan dengan menggunakan analisis kuadran dengan diagram kartesius.

\section{HASIL PENELITIAN}

Dalam penelitian ini, Analisis Kuadran yang dilakukan peneliti terhadap atribut-atribut tingkat kepuasan ibu bersalin pada bidan di wilayah kerja Puskesmas Arjasari Kabupaten Bandung berdasarkan unsur-unsur /determinan kualitas mutu diperoleh hasil seperti yang terlihat pada gambar 1.1

\section{Gambar 1.}

\section{Diagram Matriks Kuadran Importance Performance Analysis kepuasan ibu bersalin pada bidan}

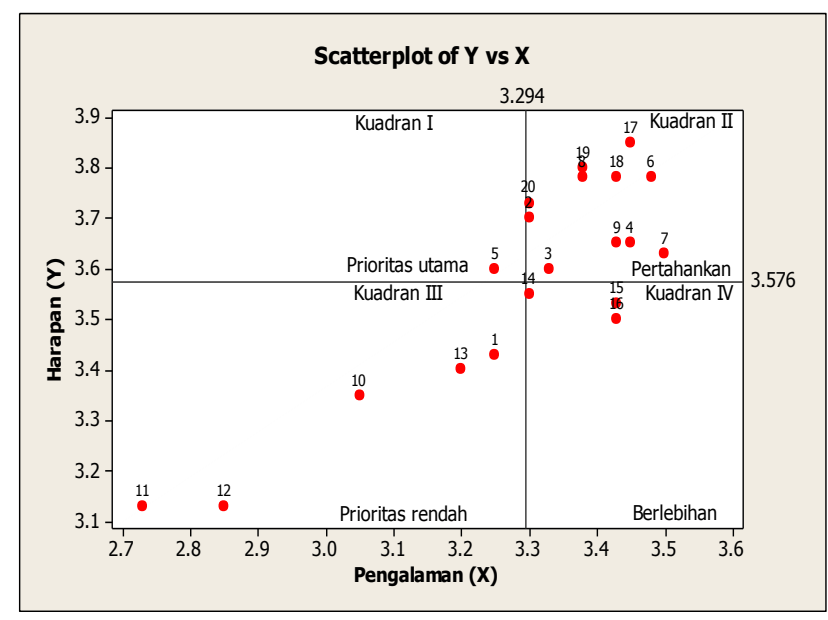

Adapun interpretasi dari diagram kartesius tersebut dapat dijelaskan sebagai berikut:

\section{Kuadran I}

Kuadran I pada diagram di atas memuat atribut yang tinggi menurut harapan responden, namun dengan pengalaman yang rendah. Harapan ibu bersalin yang tinggi belum tercapai dari pelayanan pertolongan persalinan oleh Bidan. Hal ini mengindikasikan bahwa Bidan perlu melakukan peningkatan pelayanan pertolongan persalinan untuk memenuhi kepuasan ibu bersalin. Atribut yang termasuk ke dalam Kuadran I merupakan faktor kelemahan Bidan dalam pelayanan pertolongan persalinan. 
Terdapat satu atribut yang termasuk dalam Kuadran I, yakni atribut 5 yang termasuk dalam dimensi reliability yaitu : Keterampilan penolong persalinan dalam menangani proses persalinan.

\section{Kuadran II}

Kuadran II mencakup atribut-atribut yang tinggi menurut harapan dan pengalaman responden. Dengan kata lain harapan responden telah tercapai dengan pengalaman terhadap kinerja bidan yang memuaskan. Bagi bidan, hal ini menjadi informasi bahwa atribut-atribut yang ada dalam Kuadran II telah memenuhi kepuasan ibu bersalin, dan menjadi faktor-faktor kekuatan/unggulan bidan, sehingga pelayanan pertolongan persalinan terhadap ibu bersalin perlu dipertahankan.

Terdapat sebelas atribut dalam Kuadran II, yakni 1 atribut dimensi reliability yaitu: Penolong persalinan memberitahu teknik persalinan seperti nafas dalam dan posisi pada waktu mengeluarkan bayi yang harus dipatuhi oleh anda; 2 atribut dimensi confidence yang meliputi: pertolongan persalinan yang telah diberikan pada anda tidak menimbulkan kelainan dan setelah persalinan penolong persalinan memberi penjelasan tentang keadaan ibu dan bayi; 4 atribut dimensi emphaty yang meliputi: penolong persalinan memiliki kepedulian yang baik, penolong persalinan membantu persalinan dengan penuh kesabaran, keramahan yang diberikan penolong persalinan, dan penolong persalinan memberikan perhatian terhadap keluhan anda dan keluarga; serta 4 atribut dimensi responsiveness yang meliputi: kemampuan penolong persalinan cepat tanggap terhadap keluhan anda setelah persalinan, tindakan yang cepat dari penolong persalinan saat anda membutuhkan bantuan, penolong persalinan memberi tindakan untuk mengurangi nyeri pada saat dan setelah persalinan dan penolong persalinan memeriksa anda setelah anda bersalin dengan rutin.

\section{Kuadran III}

Kuadran III mencakup atribut-atribut yang rendah menurut harapan dan pengalaman responden. Dengan kata lain harapan responden yang rendah bersesuaian dengan pengalaman (kinerja bidan) yang belum memuaskan responden. Hal ini mengindikasikan belum optimalnya pelayanan pertolongan persalinan oleh bidan. Namun, hal tersebut pula mengindikasikan bahwa bidan belum perlu melakukan upayaupaya peningkatan pelayanan pertolongan persalinan, karena mengingat harapan responden terhadap atribut-atribut tersebut juga rendah. Dengan begitu bidan di wilayah kerja Puskesmas Arjasari Kabupaten Bandung dapat menjadikan atribut-atribut dalam Kuadran III sebagai prioritas rendah untuk dilakukan upaya-upaya peningkatan.

Berdasarkan matriks kuadran di atas, terdapat lima atribut dalam Kuadran III, yakni 1 atribut dimensi reliability yaitu: Secara keseluruhan kecepatan dan ketanggapan penolong persalinan baik; 2 atribut dimensi emphaty yang meliputi: penolong persalinan membantu anda pada waktu buang air kecil (BAK) dan buang air besar (BAB); serta 2 atribut dimensi tangibles yang meliputi: informasi tentang tarif sudah diinformasikan dengan jelas oleh penolong persalinan dan ketersediaan alat yang digunakan penolong persalinan.

\section{Kuadran IV}

Kuadran IV mencakup atribut-atribut yang tinggi menurut pengalaman dan rendah menurut harapan responden. Dengan kata lain harapan responden yang rendah bersesuaian dengan pengalaman responden yang memuaskan. Pelayanan pertolongan persalinan yang dilakukan oleh bidan sangat memuaskan. Oleh karena itu, bidan di 
wilayah kerja Puskesmas Arjasari Kabupaten Bandung lebih disarankan untuk mengalihkan pelayanan pertolongan persalinan pada yang lain.

Terdapat tiga atribut yang termasuk dalam Kuadran IV, yakni tiga atribut subvariabel dimensi tangibles yang meliputi: penolong persalinan menjaga agar alat-alat yang digunakan selalu bersih, penolong persalinan mencuci tangan sebelum melakukan tindakan, dan penolong persalinan mencuci tangan setelah melakukan tindakan.

Gambar 2.

\section{Diagram Matriks Kuadran Importance Performance Analysis Dukun Bayi}

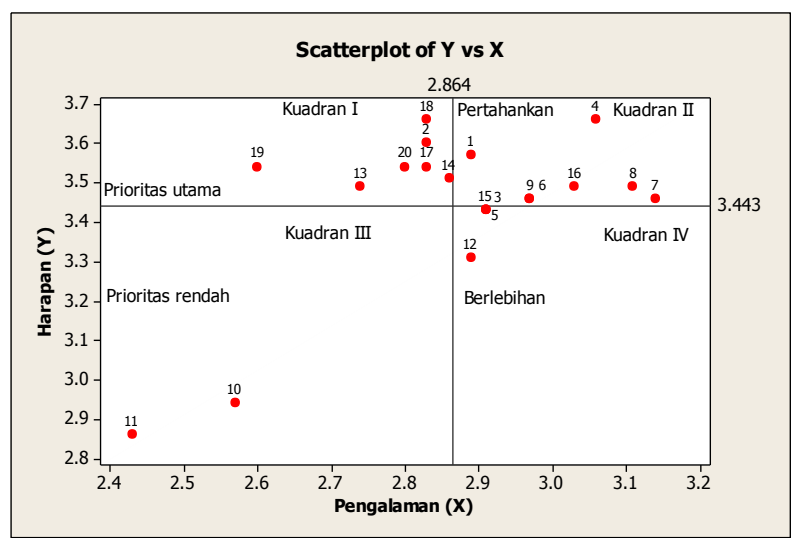

Adapun interpretasi dari diagram kartesius tersebut dapat dijelaskan sebagai berikut:

\section{Kuadran I}

Kuadran I pada diagram di atas memuat atribut yang tinggi menurut harapan responden, namun dengan pengalaman yang merupakan kinerja Dukun Bayi yang rendah. Harapan ibu bersalin yang tinggi belum tercapai dari pelayanan pertolongan persalinan oleh Dukun Bayi. Hal ini mengindikasikan bahwa Dukun Bayi perlu melakukan peningkatan pelayanan pertolongan persalinan untuk memenuhi kepuasan ibu bersalin. Atribut yang termasuk ke dalam Kuadran I merupakan faktor kelemahan Dukun bayi dalam pelayanan pertolongan persalinan.
Terdapat tujuh atribut yang termasuk dalam Kuadran I, yakni 1 atribut dimensi reliability yaitu: Penolong persalinan memberitahu teknik persalinan seperti nafas dalam dan posisi pada waktu mengeluarkan bayi yang harus dipatuhi oleh anda; 2 atribut dimensi tangibles yang meliputi: ketersediaan alat yang digunakan penolong persalinan dan penolong persalinan menjaga agar alat-alat yang digunakan selalu bersih; dan 4 atribut dimensi responsiveness yang meliputi: kemampuan penolong persalinan cepat tanggap terhadap keluhan anda setelah persalinan, tindakan yang cepat dari penolong persalinan saat anda membutuhkan bantuan, penolong persalinan memberi tindakan untuk mengurangi nyeri pada saat dan setelah persalinan dan penolong persalinan memeriksa anda setelah anda bersalin dengan rutin.

\section{Kuadran II}

Kuadran II mencakup atribut-atribut yang tinggi menurut harapan dan pengalaman responden. Dengan kata lain harapan responden telah tercapai dengan pengalaman (kinerja dukun bayi) yang memuaskan. Bagi dukun Dukun bayi, hal ini menjadi informasi bahwa atribut-atribut yang ada dalam Kuadran II telah memenuhi kepuasan ibu bersalin, dan menjadi faktor-faktor kekuatan/unggulan Dukun bayi, sehingga pelayanan pertolongan persalinan terhadap ibu-ibu perlu dipertahankan.

Terdapat tujuh atribut dalam Kuadran II, yakni 1 atribut dimensi reliability yaitu: Secara keseluruhan kecepatan dan ketanggapan penolong persalinan baik; 1 atribut dimensi confidence yaitu setelah persalinan penolong persalinan memberi penjelasan tentang keadaan ibu dan bayi; 4 atribut dimensi emphaty yang meliputi: penolong persalinan memiliki kepedulian yang baik, penolong persalinan membantu 
persalinan dengan penuh kesabaran, keramahan yang diberikan penolong persalinan, dan penolong persalinan memberikan perhatian terhadap keluhan anda dan keluarga; serta 1 atribut dimensi tangibles yaitu penolong persalinan mencuci tangan setelah melakukan tindakan.

\section{Kuadran III}

Kuadran III mencakup atribut-atribut yang rendah menurut harapan dan pengalaman (kinerja) responden. Dengan kata lain harapan responden yang rendah bersesuaian dengan pengalaman (kinerja dukun bayi) yang belum memuaskan responden. Hal ini mengindikasikan belum optimalnya pelayanan pertolongan persalinan oleh dukun bayi. Namun, hal tersebut pula mengindikasikan bahwa dukun bayi belum perlu melakukan upaya-upaya peningkatan pelayanan pertolongan persalinan, karena mengingat harapan responden terhadap atribut-atribut tersebut juga rendah. Dengan begitu dukun bayi di wilayah kerja Puskesmas Arjasari Kabupaten Bandung dapat menjadikan atribut-atribut dalam Kuadran III sebagai prioritas rendah untuk dilakukan upaya-upaya peningkatan.

Berdasarkan matriks kuadran di atas, terdapat dua atribut dalam Kuadran III, yakni 2 atribut dimensi emphaty yang meliputi: penolong persalinan membantu anda pada waktu buang air kecil (BAK) dan buang air besar (BAB).

\section{Kuadran IV}

Kuadran IV mencakup atribut-atribut yang tinggi menurut pengalaman dan rendah menurut harapan responden. Dengan kata lain harapan responden yang rendah bersesuaian dengan pengalaman responden yang memuaskan. Pelayanan pertolongan persalinan yang dilakukan oleh Dukun Bayi sangat memuaskan. Oleh karena itu, Dukun Bayi di wilayah kerja Puskesmas Arjasari Kabupaten Bandung lebih disarankan untuk mengalihkan pelayanan pertolongan persalinan pada yang lain.

Terdapat empat atribut yang termasuk dalam Kuadran IV, yakni 2 atribut dimensi confidence yang meliputi: pertolongan persalinan yang telah diberikan pada anda tidak menimbulkan kelainan dan keterampilan penolong persalinan dalam menangani proses persalinan; 2 atribut dimensi tangibles yaitu informasi tentang tarif sudah diinformasikan dengan jelas oleh penolong persalinan; dan penolong persalinan mencuci tangan sebelum melakukan tindakan.

\section{PEMBAHASAN}

\section{Unsur Kehandalan (Realibility)}

Pada dasarnya ibu bersalin yang menerima pertolongan dari penolong persalinan dengan membawa harapan bahwa masalah kesehatan yang sedang dialaminya dapat teratasi dengan pertolongan penolong persalinannya. Penilaian ibu bersalin terhadap kemampuan penolong persalinan dalam melaksanakan pertolongan persalinan yang meliputi kehandalan (ketepatan dan kecepatan), atau unsur reliabilitas (kehandalan), setelah ibu bersalin membandingkan antara harapan yang diinginkan dengan kenyataan /pengalaman pertolongan persalinan yang ibu bersalin terima selama proses persalinan dan setelah Ia bersalin.

Pada pertolongan yang dilakukan oleh bidan, substansi unsur realibilitas yang masuk dalam kuadran I tidak ada. Gambaran ini menunjukan bahwa pertolongan persalinan yang telah diterima oleh klien dilihat dari segi kemampuan Bidan tidak menimbulkan keluhan atau masalah dan klien merasa tidak adanya ketidakpuasan dari pertolongan persalinan yang diberikan. Dan unsur realibilitas yang masuk ke dalam kuadran II yaitu item nomor 2. Gambaran ini 
menunjukkan bahwa Ibu Bersalin merasa puas terhadap pertolongan persalinan dimana terdapat kesesuaian penilaian antara harapan yang tinggi dan pengalaman yang dirasakan menunjukkan kepuasan yang tinggi pula. Dilihat dari tingkat pendidikannya bidan diharapkan dapat memberikan pertolongan persalinan dengan kompeten dalam profesinya dan kiranya dapat melaksanakan pertolongan persalinan secara cepat dan tepat, sesuai tugas dan wewenang bidan. Dalam hal ini bidan telah sepenuhnya melaksanakan harapan klien (Ibu Bersalin) terhadap pertolongan persalinan yang diterimanya. Pada kuadran III terdapat item nomor 1, dimana hal ini menggambarkan bahwa kemampuan bidan cepat dan tanggap dalam melaksanakan tugasnya. Harapan Ibu Bersalin terhadap substansi ini rendah dan kenyataanya bidan memberikan pelayanan biasa-biasa saja sehingga bukan menjadi prioritas untuk diperbaiki, namun dipandang perlu untuk ditingkatkan. Substansi dari unsur realibilitas yang masuk dalam kuadran IV tidak ada. Gambaran ini menunjukkan bahwa faktorfaktor yang mempengaruhi kepuasaan dinilai klien rendah terhadap harapan pelaksanaannya, namun kenyataan pelaksanaan kinerja rendah, sehingga bukan merupakan suatu keadaan yang berlebihan sehingga tidak perlu untu dikurangi ata ditiadakan.

Sedangkan pada pertolongan yang dilakukan oleh Dukun Bayi, unsur reliabilitas yang masuk dalam kuadran I yaitu item nomor 2, penolong persalinan memberitahu teknik persalinan yang harus dipatuhi, hal ini dinilai oleh klien sangat penting akan tetapi Dukun Bayi belum melaksanakan sesuai harapan klien sehingga menimbulkan kekecewaan pada klien atau perasaan tidak puas, untuk itu hal tersebut menjadi prioritas utama untuk diadakan perubahan ke arah yang lebih baik. Hal ini dapat terjadi karena keterbatasan pendidikan yang serta pengetahuan yang dimiliki oleh Dukun Bayi. Pengobatan yang dihasilkan oleh Dukun Bayi adalah kebudayaan masyarakat (Notoatmodjo, 2003). Jadi jika teknik persalinan yang seharusnya diberikan ketika persalinan diabaikan oleh Dukun Bayi, hal ini tidak diajarakan dalam kebudayaanya sehingga ia merasa tidak perlu melakukannya. Pada kuadran II terdapat item nomor 1. Gambaran ini menunjukkan bahwa Dukun Bayi telah memberikan pertolongan persalinan dengan cepat dan tanggap. Substansi ini dianggap penting oleh klien dan Dukun Bayi telah melaksanakannya dengan baik dan klien merasa puas, maka Dukun Bayi harus mempertahankannya. Walaupun dukun bayi memiliki keterbatasan pendidikan, tapi Ia dapat cepat dan tanggap dalam menangani persalinan klien. Pada kuadran III dan IV tidak terdapat substansi unsur realibilitas. Jadi tidak ada yang perlu dilakukan peningkatan pelayanan.

\section{Unsur Keyakinan (Confidence)}

Pada pertolongan persalinan yang dilakukan oleh bidan, substansi dari unsur keyakinan yang masuk ke dalam kuadran I yaitu item nomor 5, keterampilan penolong persalinan dalam menangani proses persalinan, hal ini dinilai oleh Ibu Bersalin sangat penting akan tetapi pada kenyataanya bidan belum melaksanakan sesuai harapannya sehingga menimbulkan kekecewaan atau perasaan tidak puas, untuk itu hal ini menjadi prioritas utama untuk diadakan perubahan kearah yang lebih baik. Apalagi bidan dengan pendidikan yang dimilikinya seharusnya memiliki pengetahuan yang kemudian dikembangkan menjadi keterampilan. Substansi dari unsur keyakinan, yang masuk ke dalam kuadran II adalah item nomor 3, dan 4. Gambaran ini menunjukkan bahwa bidan telah membina kepercayaan klien terhadapnya dengan cara telah melakukan komunikasi yang efektif dan 
memiliki pengetahuan dan kemampuan sehingga pertolongan persalinan yang diberikan tidak menimbulkan kelainan pada Ibu Bersalin . Substansi ini dianggap penting oleh Ibu Bersalin dan bidan telah melaksanakannya dengan baik. Ibu Bersalin juga merasa puas, maka bidan sebagai penolong persalinan harus mempertahankannya. Sedangkan substansi dari unsur keyakinan yang masuk ke dalam kuadran III dan IV tidak ada. Gambaran ini menunjukkan bahwa faktor-faktor yang mempengaruhi kepuasan Ibu Bersalin dianggap kurang penting oleh Ibu Bersalin dan pada kenyataanya bidan tidak melaksanakannya, jadi tidak perlu dilakukan peningkatan pelayanan.

Pada pertolongan persalinan yang dilakukan oleh Dukun Bayi, substansi dari unusr keyakinan yang masuk ke dalam kuadran I tidak ada, berarti bahwa hal tersebut bukan merupakan prioritas utama untuk dilakukan perubahan, yang berarti pula Ibu Bersalin telah merasa puas. Substansi dari unsur keyakinan, yang masuk ke dalam kuadran II adalah item 3 dan 4. Gambaran ini menunjukkan bahwa Ibu bersalin menaruh kepercayaan kepada Dukun Bayi untuk menangani persalinan walaupun mereka mengetahui pengetahuan yang didapatkan bukan dari pendidikan formal tapi turun temurun. Substansi ini dianggap penting oleh klien dan Dukun Bayi juga telah menunjukkan kinerja yang baik pula sehingga Ibu Bersalin sebagai klienya merasa puas, maka Dukun Bayi harus mempertahankannya. Substansi dari unsur keyakinan yang masuk ke dalam kuadran III tidak ada. Jadi tidak perlu dilakukan peningkatan pelayanan. Sedangkan pada kuadran IV terdapat item 5. Gambaran ini menunjukkan bahwa Dukun Bayi terampil dalam menangani persalinan didasarkan pada pengetahuan yang dimiliki- nya, dinilai oleh ibu bersalin rendah terhadap pelaksanaannya, namun dalam kenyataan pelaksanaan kinerja tinggi, sehingga merupakan suatu keadaan yang berlebihan dan memungkinkan untuk dikurangi atau ditiadakan.

\section{Unsur Empati}

Penilaian Ibu Bersalin terhadap empati dan ketulusan penolong persalinan saat melakukan pertolongan persalinan dengan tingkat kesesuaian antara harapan dan pengalaman meliputi perhatian secara individu dan kepedulian yang diberikan kepada Ibu Bersalin. Unsur empati penolong persalinan meliputi substansi item nomor 6, penolong persalinan memiliki kepedulian yang baik. Kepedulian yang dimaksud di sini adalah bagaimana penolong persalinan memperhatikan betul keadaan kesehatan serta psikologis dari Ibu Bersalin karena Ibu Bersalin memiliki tingkat stres yang tinggi. Diharapkan dengan kepedulian yang diberikan akan membuat ibu merasa nyaman dan mengurangi stress yang dialami. Item nomor 7 , penolong persalinan membantu persalinan dengan penuh kesabaran. Kesabaran penolong persalinan saat melakukan pertolongan persalinan akan menjadi suatu penialian tersendiri bagi Ibu Bersalin. Hal ini juga dapat menimbulkan rasa nyaman bagi Ibu Bersalin. Item nomor 8, keramahan yang diberikan penolong persalinan. Kadang-kadang aspek ini dilupakan oleh penolong persalinan karena yang menjadi fokus utama adalah keselamatan Ibu dan bayinya padahal secara tidak langsung klien menilai keramahan dari penolong persalinan. Salah satu hak pasien adalah berharap pemberi pelayanan memberikan respon yang layak atas permintaan pasien akan pelayanan (Wolf, 1987). Item nomor 9, penolong persalinan memberikan perhatian terhadap keluhan anda 
dan keluarga. Setiap keluhan adalah hadiah jika ditangani dengan baik (Kotler, 2006). Oleh karena itu perhatian terhadap keluhan penolong persalinan merupakan hal yang penting untuk dilaksanakan oleh penolong persalinan karena dapat menimbulkan rasa puas apabila ditangani dengan baik. Item nomor 10 dan 11, penolong persalinan membantu anda pada waktu BAK (Buang Air Kecil/kencing) dan BAB (Buang Air Besar).

\section{Unsur Berwujud atau kenyataan (Tangibels)}

Unsur kenyataan pada saat ibu menerima pertolongan persalinan meliputi item nomor 12, informasi tentang tarif sudah diinformasikan dengan jelas oleh penolong persalinan. Penolong persalinan melakukan tindakan ini agar terjadi kesepakatan antara penolong persalinan dengan klien ataupun keluarganya. Sehingga ketika proses persalinan berlangsung tidak ada beban lagi mengenai biaya yang harus dibayar atas jasa pertolongan persalinan penolong persalinan tersebut. Item nomor 13, ketersediaan alat yang digunakan penolong persalinan. Hal ini dapat memperlancar dilakukannya pertolongan persalinan sehingga keselamatan ibu dan bayinya pun dapat terwujud. Item nomor 14, penolong persalinan menjaga agar alat-alat yang digunakan selalu bersih. Penolong persalinan harus menjaga agar alatalat yang digunakan bersih untuk meminimalkan terjadinya infeksi pada saat pertolongan persalinan berlangsung sehingga tidak menimbulkan kelainan pada ibu dan bayinya. Pertolongan persalinan yang dilakukan oleh penolong persalinan sangat beresiko untuk menimbulkan infeksi pada kliennya oleh karena itu tugas dari penolong persalinan untuk mencegah terjadinya infeksi. Salah satu caranya dengan menjaga alat-alat yang akan dipakai pada saat pertolongan persalinan. Item nomor 15 dan 16, Penolong persalinan mencuci tangan sebelum dan sesudah melakukan tindakan. Hal ini dmaksudkan agar ketika memberikan pertolongan persalinan, penolong persalinan tidak menularkan kuman penyakit yang akan menginfeksi Ibu Bersalin.Kemungkinan terbesar terjadinya infeksi pada Ibu bersalin ialah bahwa si penolong sendiri membawa kuman ke dalam rahim, mungkin juga tangan penolong atau alat-alatnya masuk membawa kuman-kuman dari luar (Sastrawinata, 1989). Ini juga merupakan standar prosedur pelayanan kesehatan yang berupa pertolongan persalinan. Tapi pada kenyataannya ibu yang bersalin di desa tidak terlalu memperhatikan standar pelayanan kesehtan tersebut karena keterbatasan pengetahuan.

\section{Unsur Ketanggapan (Responsiveness)}

Penilaian terhadap ketanggapan (Responsiveness) penolong persalinan dalam memberikan pertolongan persalinan yang meliputi kemampuan penolong persalinan cepat tanggap terhadap keluhan setelah persalinan, tindakan cepat dari penolong persalinan saat Ibu membutuhkan bantuan, penolong persalinan memberi tindakan untuk mengurangi nyeri pada saat dan setelah persalinan, penolong persalinan memeriksa setelah Ibu Bersalin dengan rutin, setelah membandingkan harapan yang diinginkan Ibu Bersalin dengan pengalaman dan kenyaataanya.

Substansi unsur ketanggapan penolong persalinan meliputi item nomor 17, kemampuan penolong persalinan cepat tanggap terhadap keluhan setiap persalinan. Item nomor 18, tindakan cepat dari penolong persalinan saat Ibu membutuhkan bantuan. Adanya tanggapan yang cepat dan sesuai dengan kebutuhan klien akan menimbulkan rasa puas, tetapi apabila ada keluhan yang tidak segera ditanggapi akan menimbulkan ketidakpuasan terhadap pelayanan akan 
permanen dan tidak dapat diubah lagi (Tjiptono, 2000). Setiap keluhan adalah hadiah jika ditangani dengan baik (Kotler, 2006). Jadi setiap keluhan bila ditanggapi dengan cepat dan sesuai akan menjadi suatu penilaian dari Ibu Bersalin yang menunjukkan kepuasan. Item nomor 19, penolong persalinan memberi tindakan untuk mengurangi nyeri pada saat dan setelah persalinan. Wanita kadang-kadang merasa bahwa nyeri persalinan adalah sesuatu yang penting secara psikologis karena menguji komitmennya kepada bayi ( Nolan Mary, 2004). Jadi setiap Penolong persalinan harus dapat mengurangi nyeri pada saat atau setelah bersalin karena hal ini dianggap penting oleh Ibu Bersalin. Item nomor 20, penolong persalinan memeriksa setelah Ibu Bersalin dengan rutin. Pemeriksaan setelah kala nifas sebenarnya sangat penting dilakukan untuk mendapatkan penjelasan yang berharga dari penolong persalinan yang menolong persalinan itu (Manuaba, 1999). Pemeriksaan kala nifas ini dilakukan sebagai bentuk dari ketanggapan penolong persalinan jika terdapat masalah setelah ibu melahirkan. Agar tercipta suatu kesan yang baik bagi klien sebagai pengguna jasa pelayanan, maka pihak penyelenggara harus mampu mengantisipasi masalah yang dihadapi klien dengan baik, cepat dan tepat (Supranto, 1997).

\section{KESIMPULAN DAN SARAN}

\section{Kesimpulan}

Tingkat kepuasan ibu bersalin dengan bidan dan dukun bayi menunjukkan hasil berbeda dari setiap elemen kepuasan. Pada ibu bersalin dengan penolong persalinan bidan unsur yang menjadi prioritas utama dan harus dilaksanakan atau diperbaiki agar sesuai dengan harapan Ibu Bersalin adalah item nomor 5. Unsur ini terdapat pada kuadran I.
Terdapat 11 item pada kuadaran II merupakan unsur yang perlu dipertahankan pelaksanaannya, karena sudah sesuai dengan harapan pelanggan. Terdapat 5 item pada Kuadran III merupakan unsur-unsur yang dinilai kurang penting oleh Ibu Bersalin dan menjadi prioritas rendah untuk dilakukan upaya-upaya peningkatan walaupun kinerja bidan juga rendah. Terdapat 3 item pada kuadran IV merupakan unsur-unsur yang pelaksanaannya dilakukan dengan sangat baik oleh Bidan, namun dinilai kurang penting oleh Ibu Bersalin, sehingga terkesan berlebihan.

Ini menjadi perhatian bagi tenaga kesehatan terutama bidan untuk meningkatkan pelayanan yang diberikan pada ibu bersalin. Terutama pada dimensi yang dirasa kurang sehingga akan meningkatkan kepuasan ibu bersalin. Dampaknya ibu akan bersalin pada tenaga kesehatan dan meninggalkan dukun bayi sebagai penolong persalinannya.

\section{DAFTAR PUSTAKA}

Dinkes Kab. Bandung. 2007. Profil Kesehatan Kabupaten Bandung. Bandung.

Dinkes Kab Bandung. 2008. Kematian Ibu danBayi Meningkat. Available online at http://bandungkab.go.id/index .php?option $=$ com_content $\&$ task $=$ view $\& \mathrm{id}=1364 \&$ Itemid=22. (diakses April 2009).

Kotler, Philip. 2006. Manajemen Pemasaran, Jilid II. Jakarta: PT INDEKS Kelompok Gramedia.

Manuaba, Ida Bagus Gde. 1999. Memahami Kesehatan Reproduksi Wanita. Jakarta: Arcan.

Nolan, Mary. 2004. Kehamilan \& Melahirkan. Jakarta: Arcan. 
Tingkat Kepuasan Ibu yang Bersalin pada Bidan dan Dukun Bayi (Suci Noor Hayati)

Notoatmodjo. 2003. Promosi dan Perilaku Kesehatan Masyarakat. Jakarta: Rineka Cipta.

Nursalam. 2008. Konsep dan Penerapan Metodologi Penelitian Ilmu Keperawatan. Jakarta: Salemba Medika.
Supranto, J.2006. Pengukuran Tingkat Kepuasan Pelanggan. Jakarta: PT Rineka Cipta.

Tjiptono, F.,et al. 2004. Service, Quality, Satisfaction. Jakarta: Andi Offset 